\title{
Effect of Multi-Enzyme Mixtures on Performance and Nutrient Utilization in Broilers Fed Diets Containing Different Types of Cereals and Industrial By-Products
}

\author{
Samuel M. Waititu ${ }^{2}$, Anna Rogiewicz ${ }^{2}$, Bogdan A. Slominski ${ }^{2}$, Joyce G. Maina ${ }^{3}$, \\ James O. Ochanda ${ }^{1}$ and Charles M. Nyachoti ${ }^{2}$ \\ ${ }^{1}$ Center for Biotechnology and Bioinformatics, University of Nairobi, Kenya \\ ${ }^{2}$ Department of Animal Science, University of Manitoba, Winnipeg, Canada, R3T2N2 \\ ${ }^{3}$ Department of Animal Production, University of Nairobi, Kenya
}

\begin{abstract}
The effect of 3 multi-enzyme mixtures (MEM), A, B and C, having equivalent phytase activities but with different activities of carbohydrases (except invertase) and protease on growth performance and nutrient utilization in broiler chickens fed diets containing different types of cereals and industrial by-products was investigated. Day-old broiler chicks $(\mathrm{N}=400)$ were distributed in a completely randomized design, with 8 treatments of 10 replicates each. Two control diets, one consisted of wheat, corn, soybean meal, canola meal and wheat-corn distillers dried grains with solubles (WCS), and one with sorghum, cottonseed meal, sunflower meal and brewer's dried grains (SCS) were formulated and fed to birds without or with one of the 3 MEM. Feed intake (FI) and body weight gain (BWG) were determined weekly. On day 20 excreta samples were collected for determination of total tract apparent retention (TTAR) of nutrients and nitrogen corrected apparent metabolizable energy $\left(\mathrm{AME}_{\mathrm{n}}\right)$. On day 22, eight birds per treatment were killed by cervical dislocation to collect jejunal and ileal digesta for determination of viscosity and apparent ileal digestibility (AID) of nutrients, respectively. Diet and enzyme interactions were only detected for overall feed conversion ratio (FCR, $P<0.001$ ) with MEM B and MEM C shown to reduce overall FCR in birds offered SCS and WCS diets, respectively. Most observed differences were due to diet type showing that birds offered WCS diets had higher FI $(P<0.0001)$ and BWG $(P<0.0001)$ throughout the experiment, higher wk 1 FCR $(P<$ $0.0001)$, higher $\mathrm{AME}_{\mathrm{n}}(P<0.0001)$ and TTAR of $\mathrm{P}(P<0.0001)$ and NDF $(P<0.0001)$ compared with SCS diets. In conclusion, the MEM did not affect growth performance and nutrient utilization though MEM B and MEM C acted differently to reduce overall FCR in birds offered SCS and WCS diets, respectively.
\end{abstract}

Key words: broiler, multi-enzyme mixtures, nutrient utilization, performance

J. Poult. Sci., 51: 402-410, 2014

\section{Introduction}

Corn, wheat and soybean are major ingredients of poultry feed but are not readily available for feed production in several parts of the world due to unfavourable agroclimatic conditions. In addition, the high demand for corn, wheat and soybean for human consumption and biofuel production has led to a surge in their prices worldwide (Ojewola et al., 2004), consequently increasing feed cost. Alternative cereals like barley, rye and sorghum can replace corn and wheat as energy sources, whereas oil meals from cottonseed

Received: November 26, 2013, Accepted: April 8, 2014

Released Online Advance Publication: May 25, 2014

Correspondence: Prof. C. M. Nyachoti, Department of Animal Science, University of Manitoba, Winnipeg, Manitoba, CANADA. R3T2N2.

(E-mail: Martin.Nyachoti@ad.umanitoba.ca) and sunflower seed, and industrial co-products such as dried distillers grains with solubles and brewers dried grains can replace soybean meal as protein sources in poultry feed (García et al., 2008; Shim et al., 2011).

However, most alternative ingredients are rich in antinutritive compounds such as soluble non-starch polysaccharides (NSP) and phytate which depress nutrient utilization and performance (Annison and Choct, 1991; Ravindran et al., 1999). This is because poultry lack endogenous NSPdegrading enzymes (Bedford, 2000; Denstadli et al., 2010) and produce insufficient amounts of phytase to properly hydrolyze phytate (Ravindran et al., 1995). Supplemental exogenous carbohydrases and phytases can hydrolyze NSP (Meng et al., 2005; Selle et al., 2009; Wang et al., 2009) and phytate (Angel et al., 2006; Applegate et al., 2003; Leytem et al., 2007; Penn et al., 2004) in broiler diets, respectively, 
thereby improve nutrient utilization and performance.

We hypothesized that supplementation of MEM having a broad spectrum of carbohydrase activities can mitigate the negative effects exhibited by NSP-rich alternative feedstuff in broilers. The carbohydrases would enhance NSP hydrolysis in the diet thereby improve access of endogenous digestive enzymes in the gut to their substrates, phytase and protease would enhance dietary phytate and protein hydrolysis, respectively. Collectively, these hydrolytic actions of the MEM would enhance growth performance and nutrient utilization. Our objective was to compare the effectiveness of 3 MEM having equivalent phytase activities but with different activities of carbohydrases (except invertase) and protease on growth performance and nutrient utilization in broiler chickens fed diets consisted of wheat, corn, soybean meal, canola meal and wheat-corn distillers dried grains with solubles (WCS) or with sorghum, cottonseed meal, sunflower meal and brewer's dried grains (SCS).

\section{Materials and Methods}

\section{Birds and Housing}

Four hundred broiler chicks (Ross 308, Carleton Hatcheries Ltd, Grunthal, Manitoba) were randomly divided into 8 groups, each having ten replicates of 5 chicks. The brooder and room temperature was set at $32^{\circ} \mathrm{C}$ and $29^{\circ} \mathrm{C}$, respectively, during the first 7 days. Thereafter, heat supply in the brooder was switched off and room temperature was maintained at $29^{\circ} \mathrm{C}$ throughout the experiment. Light was on throughout the experiment. All experimental procedures were reviewed and approved by the University of Manitoba Animal Care Protocol Management and Review Committee, and birds were handled in accordance with the Canadian Council on Animal Care guidelines (CCAC, 1993).

\section{Experimental Diets}

Two control diets were formulated to meet the National Research Council (NRC, 1994) specifications for broiler chickens (Table 1): WCS diet consisted of wheat, corn, soybean meal, canola meal and wheat-corn distillers dried grains with solubles, and SCS diet consisted of sorghum, cottonseed meal, sunflower meal and brewer's dried grains. The SCS diet represents a practical broiler starter diet that can be used in regions where the availability of wheat, corn and soybean is limited.

The control diets were fed to the birds without or with one of 3 MEM, A, B or C, each concocted to provide protease and a broad spectrum of carbohydrases at different activities (except invertase) and equivalent phytase activity. The MEM were supplied by Canadian Bio-systems Inc, Calgary, Alberta, Canada and the analyzed activities of their constituent enzymes are shown in Table 3. Each diet contained titanium dioxide $(0.3 \%)$ as an indigestible marker.

\section{Experimental Procedures}

Birds had free access to feed and water throughout the experiment. Body weight and feed consumption per cage were determined weekly after withdrawing feed for 4 hours on day 7,14 , and 21 . On day 20, non-contaminated excreta were collected for determination of total tract apparent
Table 1. Composition of basal diets (as-fed basis)

\begin{tabular}{|c|c|c|}
\hline & \multicolumn{2}{|c|}{ Basal diets } \\
\hline & WCS & SCS \\
\hline \multicolumn{3}{|l|}{ Ingredient, \% } \\
\hline Wheat & 36.00 & - \\
\hline Corn & 24.00 & - \\
\hline Soybean meal (46 \%) & 18.50 & - \\
\hline Canola meal & 5.00 & - \\
\hline Wheat-corn DDGS ${ }^{1}$ & 5.00 & - \\
\hline Cottonseed meal & - & 25.82 \\
\hline Sorghum (low tannin) & - & 35.50 \\
\hline Sunflower meal & - & 15.80 \\
\hline Brewer's dried grains & - & 9.00 \\
\hline Menhaden fish meal $(60 \%)$ & 5.00 & 5.00 \\
\hline Canola oil & 2.87 & 5.30 \\
\hline Calcium carbonate & 1.10 & 0.82 \\
\hline Dicalcium phosphate & 0.70 & 0.65 \\
\hline Mineral premix ${ }^{2}$ & 0.50 & 0.50 \\
\hline Vitamin premix ${ }^{3}$ & 1.00 & 1.00 \\
\hline Titanium dioxide & 0.30 & 0.30 \\
\hline DL-Methionine & 0.06 & 0.05 \\
\hline L-Lysine-HCl & - & 0.20 \\
\hline L-Threonine & - & 0.06 \\
\hline \multicolumn{3}{|l|}{ Calculated composition } \\
\hline $\mathrm{ME}, \mathrm{kcal} / \mathrm{kg}$ & 3,000 & 2,970 \\
\hline $\mathrm{CP}, \%$ & 22.00 & 22.50 \\
\hline $\mathrm{Ca}, \%$ & 1.00 & 1.00 \\
\hline Non-phytate P, \% & 0.45 & 0.45 \\
\hline Lysine, $\%$ & 1.11 & 1.12 \\
\hline Methionine, \% & 0.50 & 0.50 \\
\hline \multicolumn{3}{|l|}{ Analysed composition } \\
\hline $\mathrm{AME}_{\mathrm{n}}, \mathrm{kcal} / \mathrm{kg}$ & 2,802 & 2,594 \\
\hline $\mathrm{CP}, \%$ & 22.75 & 23.03 \\
\hline $\mathrm{Ca}, \%$ & 1.15 & 1.07 \\
\hline Non-phytate $\mathrm{P}, \%$ & 0.50 & 0.70 \\
\hline Phytate P, \% & 0.23 & 0.31 \\
\hline Lysine, $\%$ & 1.00 & 1.13 \\
\hline Methionine, $\%$ & 0.40 & 0.44 \\
\hline Neutral detergent fibre, $\%$ & 12.44 & 18.84 \\
\hline Non-starch polysaccharides, $\%$ & 10.50 & 13.27 \\
\hline
\end{tabular}

${ }^{1}$ DDGS obtained from using $70 \%$ wheat and $30 \%$ corn as feedstock in ethanol production;

${ }^{2}$ Mineral premix provided per kilogram of diet: manganese, $55 \mathrm{mg}$; zinc, $50 \mathrm{mg}$; iron, $80 \mathrm{mg}$; copper, $5 \mathrm{mg}$; selenium, $0.1 \mathrm{mg}$; iodine, $0.36 \mathrm{mg}$; sodium, $1.6 \mathrm{~g}$.

${ }^{3}$ Vitamin premix provided per kilogram of diet: retinyl acetate, 8,250 IU; cholecalcipherol 1,000 IU; DL-alpha-tocopherol, $11 \mathrm{IU}$; cyanocobalamin, $0.012 \mathrm{mg}$; phylloquinone, $1.1 \mathrm{mg}$; niacin, $53 \mathrm{mg}$; choline, $1,020 \mathrm{mg}$; folacin, $0.75 \mathrm{mg}$; biotin, $0.25 \mathrm{mg}$; riboflavin, $5.5 \mathrm{mg}$;

retention (TTAR) of nutrients and neutral detergent fibre (NDF), and nitrogen corrected apparent metabolizable energy $\left(\mathrm{AME}_{\mathrm{n}}\right)$, and immediately stored at $-20^{\circ} \mathrm{C}$ until required for analysis. On day 22, 8 birds randomly selected from each treatment were weighed individually then killed by cervical dislocation and jejunal (from the end of the duodenum to Meckel's diverticulum) and ileal (from Meckel's diverticulum to approximately $1 \mathrm{~cm}$ above the ileal-cecal 
junction) digesta were collected. Jejunal samples were used to determine digesta viscosity whereas ileal digesta from 2 birds within a treatment were pooled to yield 4 replicates per treatment for determination of apparent ileal digestibility (AID) of nutrients.

\section{Sample Processing and Chemical Analyses}

Jejunal digesta was mixed to obtain a homogenous mixture, which was then centrifuged at 9,000 rpm in duplicate tubes for $5 \mathrm{~min}$ in order to separate feed particles from the liquid phase. The supernatant $(0.5 \mathrm{~m} l)$ from each tube was analyzed for viscosity, which was measured in Centipoise (cps) units at $40^{\circ} \mathrm{C}$ using the Brookfield digital viscometer (model LVDVII+ CP, Brookfield Engineering Laboratories, Stoughton, MA). Ingredient and diet samples were ground to pass through a $1 \mathrm{~mm}$ screen whereas freeze-dried digesta and excreta samples were finely ground in a coffee grinder (CBG5 Smart Grind; Applica Consumer Products, Inc., Shelton, CT) and thoroughly mixed before analysis. Samples were analyzed for dry matter, NSP and fat (ingredients and diets only), nitrogen, amino acids (AA, except for excreta), $\mathrm{Ca}, \mathrm{P}$, gross energy, NDF and titanium content (except for ingredients).

Dry matter content was determined according to method 4.1.06 of AOAC (1998), and gross energy was determined using a Parr adiabatic oxygen bomb calorimeter (Parr Instrument Co., Moline, IL). Nitrogen was determined using a Leco Nitrogen analyser (Model NS-2000; LECO Corporation, St. Joseph, MI) and crude protein (CP) was calculated as $\% \mathrm{~N} \times 6.25$. Calcium and $\mathrm{P}$ contents were determined according to method 990.08 of AOAC (1990) using a Varian inductively coupled plasma mass spectrometer (Varian Inc., Palo Alto, CA, USA). Fat content was determined using a modified Randall solvent extraction method using hexane in a VELP organic solvent extraction apparatus (VELP Scientifica srl, Italy) according to method 2003.06 of AOAC (2006). Samples for AA analysis were prepared by acid hydrolysis according to method 4.1.11 of AOAC (1998). Briefly, the samples were hydrolysed with $\mathrm{HCl}$ (containing phenol) for $24 \mathrm{~h}$ at $110 \pm 2^{\circ} \mathrm{C}$ in glass tubes sealed under vacuum and amino acids were detected on a Waters ion exchange HPLC system, and the chromatograms were integrated using dedicated software with the amino acids identified and quantified using a standard amino acid solution. Cysteine and methionine were analysed as cysteic acid and methionine sulphone by oxidation with performic acid for $16 \mathrm{~h}$ at $0^{\circ} \mathrm{C}$ and neutralisation with hydrobromic acid prior to hydrolysis.

Samples for titanium analysis were ashed and digested as described by Lomer et al. (2000) and read on a Varian inductively coupled plasma mass spectrometer (Varian Inc., Palo Alto, CA). Neutral detergent fibre was determined according to Van Soest et al. (1991) using an Ankom 200 Fiber Analyzer (Ankom Technology, Fairport, NY). Nonstarch polysaccharides were determined by gas-liquid chromatography (component neutral sugars) and by colorimetry (uronic acids). The neutral sugars were analyzed as described by Englyst and Cummings (1988) with some modifications (Slominski and Campbell, 1990), whereas uronic acid was determined according to Scott (1979).

\section{Calculations and Statistical Analyses}

The digestibility of nutrients was calculated using the following equation:

$\%$ Apparent nutrient digestibility

$$
=\left\{1-\left[\left(\frac{T_{d}}{T_{f}}\right) \times\left(\frac{N_{f}}{N_{d}}\right)\right]\right\} \times 100
$$

where $\mathrm{T}_{\mathrm{d}}=$ the titanium dioxide $\left(\mathrm{TiO}_{2}\right)$ concentration in the diet, $\mathrm{T}_{\mathrm{f}}=$ the $\mathrm{TiO}_{2}$ concentration in the excreta or ileal digesta; $\mathrm{N}_{\mathrm{f}}=$ the nutrient concentration in the excreta or ileal digesta.

Nitrogen-corrected apparent metabolizable energy $\left(\mathrm{AME}_{\mathrm{n}}\right)$ content of experimental diets was calculated using the following equation:

$$
\begin{aligned}
& \operatorname{AME}_{\mathrm{n}}(\mathrm{kcal} / \mathrm{kg})= \\
& \mathrm{GE}_{\text {kcal } / \mathrm{kg} \mathrm{diet}}-\left[\mathrm{GE}_{\text {kcal } / \mathrm{kg} \mathrm{excreta}} \times\left(\mathrm{TiO}_{2} \% \text { diet } \div \mathrm{TiO}_{2 \% \text { excreta }}\right)\right] \\
& -8.22 \times\left\{\mathrm{N}_{\% \text { diet }}-\left[\mathrm{N} \% \text { excreta } \times\left(\mathrm{TiO}_{2 \% \text { diet }} \div \mathrm{TiO}_{2 \% \text { excreta }}\right)\right]\right\} \text {, }
\end{aligned}
$$

where GE is gross energy, $\mathrm{N}$ is nitrogen, $\mathrm{TiO}_{2}$ is titanium dioxide, and 8.22 is the energy equivalent of uric acid nitrogen.

Experimental data were analyzed by a general linear model (GLM) procedure of SAS (SAS Institute, Cary, NC, USA) as a $2 \times 4$ factorial array of treatments of two diet types (WCS, SCS) and 4 enzyme levels (no MEM, MEM A, MEM B, MEM C). All data were considered significantly different at $P<0.05$. Where significant differences were observed, means were separated using Tukey's mean separation procedure.

\section{Results}

The analyzed composition of sorghum, cottonseed meal, sunflower meal and brewer's dried grains are presented in Table 2. Cottonseed meal and sorghum had the highest and lowest $\mathrm{CP}$ content, respectively, among the four ingredients; values for brewer's dried grains and sunflower meal were 28.3 and $29.3 \%$, respectively. Cottonseed meal had the highest lysine content followed by sunflower meal, brewer's dried grain and then sorghum. Sorghum had the lowest methionine content compared with the other ingredients. The total NSP content was highest in cottonseed meal and lowest in sorghum (23.43 vs 5.01\%) with values for the brewer's dried grains and sunflower meal being intermediate. The SCS diet had 21\% NSP (13.27 vs $10.50 \%)$, 34\% NDF (18.84 vs $12.44 \%)$ and $26 \%$ phytate $\mathrm{P}(0.31$ vs $0.23 \%)$ contents more than the WCS diet (Table 1).

Among all response criteria measured, diet $\times$ enzyme interactions were only detected for overall feed conversion ratio (FCR) showing MEM B and MEM C lowered FCR in birds offered SCS and WCS diet, respectively (Table 4). The WCS diets resulted in significantly higher FI and BWG throughout the experiment, and lower FCR in week 1 compared with SCS diets (Table 4). Considering the enzyme effects, MEM supplementation did not affect FI and BWG 
Table 2. Analyzed composition of brewer's dried grains, cottonseed meal, sorghum and sunflower meal used in the study (as-fed basis)

\begin{tabular}{|c|c|c|c|c|}
\hline \multirow[b]{2}{*}{ Component } & \multicolumn{4}{|c|}{ Ingredients } \\
\hline & $\begin{array}{c}\text { Brewer's } \\
\text { dried grains }\end{array}$ & $\begin{array}{c}\text { Cottonseed } \\
\text { meal }\end{array}$ & Sorghum & $\begin{array}{c}\text { Sunflower } \\
\text { meal }\end{array}$ \\
\hline Gross energy, $\mathrm{kcal} / \mathrm{kg}$ & 4,815 & 4,166 & 3,914 & 4,740 \\
\hline Dry matter, \% & 92.25 & 89.82 & 87.29 & 92.13 \\
\hline Crude protein, \% & 28.29 & 41.80 & 8.93 & 29.33 \\
\hline Calcium, \% & 0.19 & 0.33 & 0.17 & 0.47 \\
\hline Total P, \% & 0.90 & 1.31 & 0.33 & 1.20 \\
\hline Phytate P, \% & 0.02 & 0.73 & 0.19 & 0.60 \\
\hline Non-phytate P, \% & 0.88 & 0.57 & 0.14 & 0.61 \\
\hline Ether extract, \% & 11.61 & 1.64 & 2.95 & 12.84 \\
\hline Neutral detergent fibre, $\%$ & 29.92 & 32.78 & 9.69 & 42.72 \\
\hline Non-starch polysaccharides, \% & 21.93 & 23.43 & 5.01 & 21.56 \\
\hline Total fibre ${ }^{1}, \%$ & 35.05 & 36.78 & 9.95 & 44.65 \\
\hline \multicolumn{5}{|l|}{ Indispensable amino acids, $\%$} \\
\hline Arginine & 0.82 & 4.41 & 0.29 & 2.17 \\
\hline Histidine & 0.56 & 1.07 & 0.19 & 0.65 \\
\hline Isoleucine & 0.66 & 1.02 & 0.30 & 0.99 \\
\hline Leucine & 2.46 & 2.32 & 1.15 & 1.81 \\
\hline Lysine & 0.57 & 1.90 & 0.22 & 1.21 \\
\hline Methionine & 0.55 & 0.60 & 0.17 & 0.61 \\
\hline Phenylalanine & 2.45 & 1.64 & 0.78 & 1.22 \\
\hline Tyrosine & 0.92 & 1.50 & 0.40 & 1.19 \\
\hline Valine & 0.19 & 0.33 & 0.17 & 0.47 \\
\hline \multicolumn{5}{|l|}{ Dispensable amino acids, $\%$} \\
\hline Alanine & 1.70 & 1.66 & 0.84 & 1.24 \\
\hline Aspartic acid & 1.49 & 3.75 & 0.63 & 2.57 \\
\hline Cysteine & 0.49 & 0.68 & 0.16 & 0.48 \\
\hline Glutamic acid & 5.09 & 8.45 & 1.85 & 5.68 \\
\hline Glycine & 0.67 & 1.64 & 0.29 & 1.50 \\
\hline Proline & 1.07 & 1.87 & 0.42 & 1.22 \\
\hline Serine & 0.89 & 1.33 & 0.34 & 1.02 \\
\hline Threonine & 0.77 & 1.07 & 0.30 & 0.65 \\
\hline \multicolumn{5}{|l|}{ NSP component sugars, $\%$} \\
\hline Rhamnose & * & * & * & 0.28 \\
\hline Arabinose & 3.68 & 3.02 & 0.93 & 2.32 \\
\hline Xylose & 7.42 & 7.99 & 0.92 & 5.25 \\
\hline Mannose & 1.37 & 0.26 & 0.15 & 0.91 \\
\hline Galactose & 1.08 & 0.76 & 0.15 & 0.75 \\
\hline Glucose & 7.34 & 7.96 & 2.50 & 7.44 \\
\hline Uronic acid & 1.04 & 3.44 & 0.51 & 4.61 \\
\hline
\end{tabular}

${ }^{1}$ Determined by summation of values of NDF and neutral-detergent-soluble non-starch polysaccharides.

* Concentration was below detectable limit.

Table 3. Composition and analyzed activities $(\mathbf{U})$ provided by constituent enzymes in the multi-enzyme mixtures (MEM) per kg of diet

\begin{tabular}{|c|c|c|c|c|c|c|c|c|c|c|}
\hline \multirow[b]{2}{*}{ Item } & \multicolumn{10}{|c|}{ Enzyme $^{1}$ activity (U/kg of diet) } \\
\hline & Cel & $\mathrm{Pec}$ & Man & Gal & Xyl & Glu & Amy & Prot & Inv & Phy \\
\hline MEM A & 1,100 & 100 & 50 & 40 & 1,000 & 250 & 10,000 & 1,000 & 600 & 500 \\
\hline MEM B & 3,000 & 800 & 300 & 40 & 850 & 600 & 2,000 & 150 & 600 & 500 \\
\hline MEM C & 5,000 & 1,000 & 400 & 1,400 & 1,500 & 1,500 & 6,000 & 600 & 600 & 500 \\
\hline
\end{tabular}

${ }^{1} \mathrm{Cel}=$ Cellulase $; \mathrm{Pec}=$ Pectinase Man $=$ Mannanase $\mathrm{Gal}=$ Galactanase $; \mathrm{Xyl}=$ Xylanase $; \mathrm{Glu}=$ Glucanase $;$ Amy $=$ Amylase $;$ Prot $=$ Protease; Inv $=$ Invertase; Phy $=$ Phytase. 
Table 4. Feed intake, body weight gain and feed conversion ratio of broilers fed diets without (- MEM) or with multienzyme mixtures (+ MEM)

\begin{tabular}{|c|c|c|c|c|c|c|c|c|c|c|c|c|c|c|c|}
\hline \multirow{2}{*}{\multicolumn{2}{|c|}{ Treatment }} & \multirow{2}{*}{\multicolumn{2}{|c|}{ Body Weight (g) }} & \multicolumn{4}{|c|}{ Feed intake (g/bird) } & \multicolumn{4}{|c|}{ Body weight gain (g/bird) } & \multicolumn{4}{|c|}{ Feed conversion ratio $(\mathrm{g} / \mathrm{g})$} \\
\hline & & & & \multicolumn{4}{|c|}{ Week } & \multicolumn{4}{|c|}{ Week } & \multicolumn{4}{|c|}{ Week } \\
\hline Diet & Enzyme & Initial & Final & 1 & 2 & 3 & Overall & 1 & 2 & 3 & Overall & 1 & 2 & 3 & Overall \\
\hline \multirow[t]{4}{*}{ WCS } & - MEM & 46 & 787 & 141 & 381 & 586 & 1108 & 101 & 263 & 377 & 741 & 1.40 & 1.45 & 1.56 & $1.50^{\mathrm{abc}}$ \\
\hline & + MEM A & 46 & 815 & 143 & 376 & 597 & 1116 & 104 & 270 & 390 & 764 & 1.37 & 1.40 & 1.53 & $1.46^{\mathrm{bcd}}$ \\
\hline & + MEM B & 46 & 816 & 140 & 408 & 591 & 1139 & 101 & 261 & 394 & 757 & 1.39 & 1.56 & 1.50 & $1.51^{\mathrm{a}}$ \\
\hline & + MEM C & 46 & 829 & 144 & 388 & 606 & 1138 & 106 & 277 & 400 & 783 & 1.36 & 1.41 & 1.51 & $1.45^{\mathrm{d}}$ \\
\hline \multirow[t]{4}{*}{ SCS } & - MEM & 46 & 752 & 120 & 351 & 588 & 1060 & 84 & 243 & 379 & 706 & 1.43 & 1.45 & 1.55 & $1.50^{\mathrm{ab}}$ \\
\hline & + MEM A & 46 & 741 & 119 & 333 & 569 & 1020 & 83 & 232 & 366 & 681 & 1.43 & 1.43 & 1.56 & $1.50^{\mathrm{abc}}$ \\
\hline & + MEM B & 47 & 751 & 119 & 340 & 558 & 1017 & 82 & 233 & 383 & 697 & 1.46 & 1.47 & 1.46 & $1.46^{\mathrm{cd}}$ \\
\hline & + MEM C & 47 & 746 & 115 & 347 & 580 & 1043 & 79 & 234 & 377 & 691 & 1.46 & 1.48 & 1.54 & $1.51^{\mathrm{a}}$ \\
\hline SEM $^{1}$ & & 0.1 & 13.3 & 3.2 & 10.3 & 11.7 & 20.5 & 2.6 & 6.2 & 7.6 & 13.5 & 0.018 & 0.031 & 0.020 & 0.015 \\
\hline \multicolumn{16}{|c|}{ Main effects } \\
\hline \multirow[t]{2}{*}{ Diet } & WCS & 47 & 812 & 142 & 388 & 595 & 1125 & 103 & 268 & 391 & 761 & 1.38 & 1.45 & 1.53 & 1.48 \\
\hline & SCS & 46 & 747 & 118 & 343 & 574 & 1035 & 82 & 236 & 376 & 694 & 1.44 & 1.46 & 1.53 & 1.49 \\
\hline \multirow[t]{4}{*}{ Enzyme } & - MEM & 46 & 770 & 130 & 366 & 587 & 1084 & 93 & 253 & 378 & 723 & 1.41 & $1.45^{\mathrm{b}}$ & $1.56^{\mathrm{a}}$ & 1.50 \\
\hline & + MEM A & 46 & 778 & 131 & 355 & 583 & 1068 & 94 & 251 & 378 & 723 & 1.40 & $1.42^{\mathrm{b}}$ & $1.54^{\mathrm{a}}$ & 1.48 \\
\hline & + MEM B & 47 & 783 & 129 & 374 & 574 & 1078 & 91 & 247 & 389 & 727 & 1.42 & $1.51^{\mathrm{a}}$ & $1.48^{\mathrm{b}}$ & 1.48 \\
\hline & + MEM C & 46 & 788 & 130 & 368 & 593 & 1090 & 93 & 256 & 389 & 737 & 1.41 & $1.44^{\mathrm{b}}$ & $1.53^{\mathrm{a}}$ & 1.48 \\
\hline \multicolumn{16}{|l|}{ P-value ${ }^{2}$} \\
\hline & Diet (D) & NS & $* * *$ & $* * *$ & $* * *$ & $*$ & $* * *$ & $* * *$ & $* * *$ & $* *$ & $* * *$ & $* * *$ & NS & NS & NS \\
\hline & Enzyme (E) & NS & NS & NS & NS & NS & NS & NS & NS & NS & NS & NS & $*$ & $* *$ & NS \\
\hline & $\mathrm{D} \times \mathrm{E}$ & NS & NS & NS & NS & NS & NS & NS & NS & NS & NS & NS & $\dagger$ & NS & $* *$ \\
\hline
\end{tabular}

${ }^{\text {a-d }}$ Means within a column with different superscripts differ at the $P$-value shown

${ }^{1} \mathrm{SEM}=$ pooled standard error of mean.

${ }^{2}$ Significance level: $\dagger P \leq 0.1, * P \leq 0.05, * * P \leq 0.001, * * * P \leq 0.0001$, NS (Not significant) $P>0.1$

but birds receiving diet supplemented with MEM B had higher FCR in wk $2(P<0.05)$ and lower FCR in wk $3(P<$ $0.001)$ compared to all groups and the non-supplemented group, respectively (Table 4). The WCS diets resulted in significantly lower AID of arginine, higher AID of histidine, leucine, lysine, methionine (Table 5), cysteine, glutamic acid, glycine, proline and serine (Table 6), higher $\mathrm{AME}_{\mathrm{n}}$ and TTAR of P and NDF compared with SCS diets (Table 7). Considering the enzyme effects, birds receiving the 3 MEM had lower $(P<0.0001)$ digesta viscosity compared to nonsupplemented group (Table 7).

\section{Discussion}

The $\mathrm{CP}$ and fat contents of sorghum and cottonseed meal were consistent with NRC (1994) values, whereas the CP content of sunflower meal was lower than that reported by Jankowski et al. (2011). The total NSP and phytate P contents of sorghum were lower than reported by NRC (1994). The total NSP and phytate P contents of cottonseed meal were higher and lower than reported NRC (1994), respectively. The reported differences in nutrient composition of the meals may be due to variations in fat content, cultivars and geographical origin.

We observed an interaction between diet and enzyme associated with overall FCR reduction in birds offered SCS and WCS diet with MEM B and MEM C, respectively. Although MEM B had lower enzyme activities than MEM C, the results imply that the two MEM acted differently in the two diets thus demonstrating the need to constitute enzyme blends and activities based on the substrate present in the feed ingredients. For instance, the high activity of xylanase and glucanase in MEM C possibly influenced hydrolysis of arabinoxylan and $\beta$-glucan, respectively, in the WCS diet than in the SCS diet as the former is rich in water soluble arabinoxylan and $\beta$-glucan (Knudsen, 1997). It is not clear why birds receiving SCS diet with MEM B had better FCR than those receiving MEM $\mathrm{C}$ which had higher carbohydrase activities. Generally, oilseed meals such as cottonseed and sunflower seed meal which were present in the SCS diet have relatively complex carbohydrate composition compared with cereals (Choct, 1997; Graham et al., 2002; Knudsen, 1997) hence introducing variations in enzyme hydrolysis. Whether MEM B enzyme activities were optimum for the SCS diet cannot be explained by the current study. However, the finding provides more insight helpful in the development of multi-enzyme blends for diets containing oilseed meals. For instance, Liu et al. (2013) reported that the optimal levels of NSP-degrading enzymes per $\mathrm{kg}$ of sample for in vitro degradation of water-soluble and total NSP in cottonseed meal were: xylanase $(1,000 \mathrm{U} / \mathrm{kg})$, mannase $(6,000 \mathrm{U} / \mathrm{kg})$, 
Table 5. Apparent ileal digestibility (\%) of indispensable amino acids of broilers fed diets without (- MEM) or with multi-enzyme mixtures (+ MEM)

\begin{tabular}{|c|c|c|c|c|c|c|c|c|c|c|}
\hline \multicolumn{2}{|c|}{ Treatment } & \multicolumn{9}{|c|}{ Amino acids ${ }^{1}$} \\
\hline Diet & Enzyme & ARG & HIS & ILE & LEU & LYS & MET & PHE & THR & VAL \\
\hline \multirow[t]{4}{*}{ WCS } & - MEM & 88.5 & 86.3 & 84.8 & 86.7 & 84.8 & 85.1 & 85.4 & 81.1 & 85.0 \\
\hline & + MEM A & 84.7 & 81.8 & 79.9 & 82.4 & 80.5 & 84.0 & 81.0 & 74.7 & 79.5 \\
\hline & + MEM B & 85.5 & 82.1 & 79.3 & 82.9 & 80.0 & 85.4 & 82.5 & 74.8 & 79.0 \\
\hline & + MEM C & 86.5 & 82.3 & 79.7 & 83.4 & 80.8 & 83.9 & 81.3 & 75.2 & 79.7 \\
\hline \multirow[t]{4}{*}{ SCS } & - MEM & 90.7 & 79.8 & 79.6 & 81.8 & 78.9 & 79.5 & 83.0 & 74.7 & 79.9 \\
\hline & + MEM A & 90.7 & 79.2 & 79.4 & 82.2 & 78.3 & 78.9 & 82.6 & 74.1 & 79.7 \\
\hline & + MEM B & 90.8 & 79.7 & 80.4 & 81.9 & 78.8 & 76.9 & 82.6 & 75.1 & 79.7 \\
\hline & + MEM C & 90.1 & 77.3 & 77.7 & 79.4 & 76.1 & 79.5 & 80.3 & 71.2 & 77.0 \\
\hline $\mathrm{SEM}^{2}$ & & 1.14 & 1.58 & 1.77 & 1.55 & 1.66 & 1.27 & 1.57 & 2.14 & 1.79 \\
\hline \multicolumn{11}{|c|}{ Main effects } \\
\hline \multirow{2}{*}{ Diet } & WCS & 86.3 & 83.1 & 80.9 & 83.9 & 81.5 & 84.6 & 82.5 & 76.5 & 80.8 \\
\hline & SCS & 90.6 & 79.0 & 79.3 & 81.3 & 78.0 & 78.7 & 82.1 & 73.8 & 79.1 \\
\hline \multirow[t]{4}{*}{ Enzyme } & - MEM & 89.6 & 83.0 & 82.2 & 84.2 & 81.8 & 82.3 & 84.2 & 77.9 & 82.5 \\
\hline & + MEM A & 87.7 & 80.5 & 79.6 & 82.3 & 79.4 & 81.5 & 81.8 & 74.4 & 79.6 \\
\hline & + MEM B & 88.1 & 80.9 & 79.8 & 82.4 & 79.4 & 81.2 & 82.5 & 75.0 & 79.3 \\
\hline & + MEM C & 88.3 & 79.8 & 78.7 & 81.4 & 78.4 & 81.7 & 80.8 & 73.2 & 78.3 \\
\hline \multicolumn{11}{|l|}{ P-values ${ }^{3}$} \\
\hline & Diet (D) & $* * *$ & $* *$ & NS & $*$ & $* *$ & $* * *$ & NS & $\dagger$ & NS \\
\hline & Enzyme (E) & NS & NS & NS & NS & NS & NS & NS & NS & NS \\
\hline & $\mathrm{D} \times \mathrm{E}$ & NS & NS & NS & NS & NS & NS & NS & NS & NS \\
\hline
\end{tabular}

${ }^{1}$ Amino acids: Arg $=$ arginine, His $=$ histidine, $\mathrm{Ile}=$ isoleucine, $\mathrm{Leu}=$ leucine, $\mathrm{Lys}=$ lysine, $\mathrm{Met}=$ methionine, Phe $=$ phenylalanine, and $\mathrm{Thr}=$ threonine

${ }^{2} \mathrm{SEM}=$ pooled standard error of mean.

${ }^{3}$ Significance level: $\dagger P \leq 0.1, * P \leq 0.05$, ${ }^{* *} P \leq 0.001, * * * P \leq 0.0001$, NS (Not significant) $P>0.1$

glucanase $(2,000 \mathrm{U} / \mathrm{kg})$ and pectinase $(3,000 \mathrm{U} / \mathrm{kg})$, respectively. These enzyme activities are higher than of the respective enzymes in the MEM used in this study except for xylanase in MEM A $(1,000 \mathrm{U} / \mathrm{kg})$ and $\mathrm{C}(1,500 \mathrm{U} / \mathrm{kg})$.

Birds fed the SCS diets had lower FI and BWG than those fed the WCS diets, due to the anti-nutritive effect of the high dietary fibre content of the SCS diet. Lack of improvement in BWG and FI following MEM supplementation in the SCS diet contradicts the findings of Cadogan et al. (2005) showing that a combination of protease, amylase and xylanase significantly enhanced BWG and FI in broilers fed sorghum-based diets. This may have been due to the multifaceted anti-nutritive effects associated with sorghum, cottonseed meal, sunflower meal and brewer's dried grains present in the SCS diet. However, the diets in the study of Cadogan et al. (2005) contained meat and bone meal and rice pollard, and the supplemented protease activity was four times higher than in the present study.

Supplementing the MEM had no effect on the AID of CP and AA, and TTAR of Ca and P in both SCS and WCS diets. Similar results were obtained by Cowieson and Adeola (2005) after supplementing xylanase, amylase, protease and phytase in corn-rye-soybean-based broiler diet formulated to be nutritionally marginal in terms of metabolizable energy,
$\mathrm{Ca}$ and $\mathrm{P}$. The additive effect of phytase on $\mathrm{CP}$ and AA digestibilities was not observed in this study. Phytase hydrolyzes phytate and in the process releases phytatebound proteins, hence improving $\mathrm{CP}$ and AA digestibilities. Dilger et al. (2004) and Ravindran et al. (2006) reported CP and AA digestibilities improvements due to phytase addition, but Zhang et al. (1999) and Onyango et al. (2005) could not show similar effects.

Birds fed the SCS diet had lower TTAR of P than those fed the WCS diet due to the high concentration of phytate-bound $\mathrm{P}(0.31 \%)$ in the SCS diet. Failure of phytase supplementation to improve digestibilities of $\mathrm{AA}$ and $\mathrm{CP}$, and retention of $\mathrm{Ca}$ and $\mathrm{P}$ was probably due to the wide dietary $\mathrm{Ca}$ to nonphytate $\mathrm{P}$ ratio $(2.3: 1)$ in WCS, which is associated with reduction of phytase efficacy due to increased precipitation of insoluble Ca-P complexes (Bar, 1971). In addition, phytate from cottonseed (an ingredient constituting $26 \%$ of the SCS diet) is more resistant to phytase activity than that from soybean meal (Han, 1988). Furthermore, phytate may inhibit proteolysis by altering the protein configuration of digestive enzymes (Singh and Krikorian, 1982) leading to decreased digestion of dietary protein.

The SCS diet had lower $\mathrm{AME}_{\mathrm{n}}$ content than WCS diet due to its high fibre content, which is known to dilute energy and 
Table 6. Apparent ileal digestibility (\%) of crude protein (CP) and dispensable amino acids in broilers fed diets without (- MEM) or with multi-enzyme mixtures (+ MEM)

\begin{tabular}{|c|c|c|c|c|c|c|c|c|c|c|}
\hline \multicolumn{2}{|c|}{ Treatment } & \multirow[b]{2}{*}{$\mathrm{CP}$} & \multicolumn{8}{|c|}{ Amino acids ${ }^{1}$} \\
\hline Diet & Enzyme & & ALA & ASP & CYS & GLU & GLY & PRO & SER & TYR \\
\hline \multirow[t]{4}{*}{ WCS } & - MEM & 84.4 & 84.5 & 79.3 & 77.9 & 90.6 & 81.3 & 88.0 & 83.0 & 86.7 \\
\hline & + MEM A & 82.9 & 79.9 & 73.9 & 73.9 & 88.1 & 75.6 & 84.3 & 78.1 & 82.5 \\
\hline & + MEM B & 84.6 & 80.5 & 73.5 & 75.1 & 88.4 & 75.8 & 84.5 & 78.5 & 83.0 \\
\hline & + MEM C & 84.7 & 79.8 & 74.0 & 74.9 & 88.4 & 75.6 & 84.7 & 79.0 & 83.1 \\
\hline \multirow[t]{4}{*}{ SCS } & - MEM & 83.6 & 80.2 & 78.2 & 65.9 & 86.4 & 73.3 & 75.5 & 75.9 & 84.2 \\
\hline & + MEM A & 83.9 & 80.3 & 77.7 & 66.2 & 86.6 & 72.4 & 74.8 & 75.3 & 83.1 \\
\hline & + MEM B & 81.1 & 80.1 & 78.6 & 63.4 & 86.4 & 74.1 & 75.6 & 76.5 & 83.2 \\
\hline & + MEM C & 81.7 & 76.9 & 75.4 & 63.8 & 84.4 & 70.5 & 72.3 & 73.0 & 80.9 \\
\hline $\mathrm{SEM}^{2}$ & & 1.36 & 1.78 & 2.05 & 1.97 & 1.24 & 2.13 & 2.02 & 2.04 & 1.65 \\
\hline \multicolumn{11}{|c|}{ Main effects } \\
\hline \multirow[t]{2}{*}{ Diet } & WCS & 84.2 & 81.2 & 75.2 & 75.4 & 88.9 & 77.1 & 85.4 & 79.6 & 83.8 \\
\hline & SCS & 82.6 & 79.4 & 77.5 & 64.8 & 85.9 & 72.6 & 74.6 & 75.2 & 82.9 \\
\hline \multirow[t]{4}{*}{ Enzyme } & - MEM & 84.0 & 82.4 & 78.8 & 71.9 & 88.5 & 77.3 & 81.7 & 79.4 & 85.5 \\
\hline & + MEM A & 83.4 & 80.1 & 75.8 & 70.0 & 87.3 & 74.0 & 79.5 & 76.7 & 82.8 \\
\hline & + MEM B & 82.9 & 80.3 & 76.1 & 69.3 & 87.4 & 74.9 & 80.0 & 77.5 & 83.1 \\
\hline & + MEM C & 83.2 & 78.4 & 74.7 & 69.3 & 86.4 & 73.0 & 78.5 & 76.0 & 82.0 \\
\hline \multicolumn{11}{|l|}{ P-value ${ }^{3}$} \\
\hline & $\operatorname{Diet}(\mathrm{D})$ & NS & NS & NS & $* * *$ & $* *$ & $* *$ & $* *$ & $* *$ & NS \\
\hline & Enzyme (E) & NS & NS & NS & NS & NS & NS & NS & NS & NS \\
\hline & $\mathrm{D} \times \mathrm{E}$ & NS & NS & NS & NS & NS & NS & NS & NS & NS \\
\hline
\end{tabular}

${ }^{1}$ Amino acids: $\mathrm{Ala}=$ alanine, $\mathrm{Asp}=$ aspartic acid, $\mathrm{Cys}=$ cysteine, $\mathrm{Glu}=$ glutamic acid, $\mathrm{Gly}=$ glycine, Pro $=$ proline, $\mathrm{Ser}=\mathrm{serine}$, and $\mathrm{Tyr}=$ tyrosine

${ }^{2} \mathrm{SEM}=$ pooled standard error of mean.

${ }^{3}$ Significance level: $\dagger P \leq 0.1,{ }^{* *} P \leq 0.001,{ }^{* * *} P \leq 0.0001$, NS (Not significant) $P>0.1$

other nutrients (Jorgensen et al., 1996). The MEM had no effect on $\mathrm{AME}_{\mathrm{n}}$ and this is similar to observations by Selle et al. (2010) who supplemented a blend of protease, xylanase, $ß$-glucanase and phytase activities to SCS or WCS broiler diets. Generally, carbohydrases are known to hydrolyze bonds between complex polysaccharides like cellulose, hemicellulose and pectins, hence, releasing starch, proteins and fatty acids bound within cell walls and thereby improving energy content of the diets (Meng and Slominski, 2005; Meng et al., 2005; Rutherfurd et al., 2007).

The lack of effect of the MEM on both performance and nutrient utilization within and between the SCS and WCS diets is multi-faceted. For instance, in each diet group, the basal and MEM supplemented diets met broilers nutritional requirements hence the failure to see enzyme effects as also observed by Selle et al. (1999). Furthermore, observed differences were mainly due to diet type owing to the antinutritive compounds present in their constituent ingredients. However, these differences did not contribute largely to the NSP and viscosity contents of the two diets hence making it difficult to clearly see carbohydrases effects.

In conclusion, the MEM did not influence performance and nutrient utilization in birds receiving SCS or WCS diet. Although MEM B had lower enzyme activities than MEM C, it reduced overall FCR birds fed SCS diet thus implying the two MEM acted differently in the two diets possibly due to differences in the carbohydrate moiety of the ingredients. Hence, to maximize beneficial effects of MEM in diets based on sorghum, cottonseed meal, sunflower seed meal and brewers dried grains or other alternative ingredients, enzyme selection and application should be based on carbohydrate composition of the substrates. Furthermore, an optimum concentration of the MEM constituents needs to be determined for each ingredient and the diet.

\section{Acknowledgments}

We thank the Department of Foreign Affairs and International Trade, Canada (DFAIT) for funding the project and the Canadian Bureau for International Education (CBIE) for overseeing the process. We thank the Canadian Biosystems Inc, Calgary, Alberta, Canada, for providing the enzyme supplements. We also thank Harry Muc and Atanas Karamanov of the Department of Animal Science, University of Manitoba, for their technical assistance. 
Table 7. Digesta viscosity, apparent total tract retention of $\mathbf{C a}, \mathbf{P}$ and neutral detergent fibre (NDF), and nitrogen-corrected apparent metabolizable energy $\left(\mathrm{AME}_{\mathrm{n}}\right)$ for broilers fed diets without (- MEM) or with multi-enzyme mixtures ${ }^{+}$ MEM)

\begin{tabular}{|c|c|c|c|c|c|c|}
\hline \multicolumn{2}{|c|}{ Treatment } & \multirow[b]{2}{*}{$\begin{array}{c}\text { Viscosity } \\
(\mathrm{cps})^{1}\end{array}$} & \multirow[b]{2}{*}{$\begin{array}{l}\mathrm{Ca} \\
(\%)\end{array}$} & \multirow[b]{2}{*}{$\begin{array}{c}\mathrm{P} \\
(\%)\end{array}$} & \multirow[b]{2}{*}{$\begin{array}{c}\mathrm{NDF} \\
(\%)\end{array}$} & \multirow[b]{2}{*}{$\begin{array}{r}\mathrm{AME}_{\mathrm{n}} \\
(\mathrm{kcal} / \mathrm{kg}\end{array}$} \\
\hline Diet & Enzyme & & & & & \\
\hline \multirow[t]{4}{*}{ WCS } & - MEM & 2.26 & 28.4 & 38.3 & 23.9 & 2,804 \\
\hline & + MEM A & 1.97 & 32.0 & 36.7 & 24.7 & 2,772 \\
\hline & + MEM B & 1.79 & 38.5 & 33.8 & 21.5 & 2,777 \\
\hline & + MEM C & 1.88 & 31.7 & 38.3 & 27.1 & 2,855 \\
\hline \multirow[t]{4}{*}{ SCS } & - MEM & 2.20 & 35.1 & 18.8 & 17.0 & 2,594 \\
\hline & + MEM A & 2.06 & 35.6 & 10.6 & 18.3 & 2,637 \\
\hline & + MEM B & 1.88 & 38.7 & 14.9 & 12.4 & 2,540 \\
\hline & + MEM C & 2.01 & 37.0 & 11.1 & 17.4 & 2,607 \\
\hline SEM $^{2}$ & & 0.077 & 3.25 & 2.91 & 1.98 & 34.8 \\
\hline \multicolumn{7}{|c|}{ Main effects } \\
\hline \multirow[t]{2}{*}{ Diet } & WCS & 1.97 & 32.7 & 36.8 & 24.3 & 2,802 \\
\hline & SOR & 2.04 & 36.6 & 13.9 & 16.3 & 2,594 \\
\hline \multirow[t]{4}{*}{ Enzyme } & - MEM & $2.23^{\mathrm{a}}$ & 31.8 & 28.6 & 20.4 & 2,699 \\
\hline & + MEM A & $2.02^{\mathrm{b}}$ & 33.8 & 23.7 & 21.5 & 2,705 \\
\hline & + MEM B & $1.83^{\mathrm{bc}}$ & 38.6 & 24.4 & 16.9 & 2,659 \\
\hline & + MEM C & $1.95^{\mathrm{c}}$ & 34.4 & 24.7 & 22.3 & 2,731 \\
\hline \multicolumn{7}{|l|}{ P-value ${ }^{3}$} \\
\hline & $\operatorname{Diet}(\mathrm{D})$ & NS & $\dagger$ & $* * *$ & $* * *$ & $* * *$ \\
\hline & Enzyme (E) & $* * *$ & NS & NS & $\dagger$ & NS \\
\hline & $\mathrm{D} \times \mathrm{E}$ & NS & NS & NS & NS & NS \\
\hline
\end{tabular}

${ }^{\mathrm{a}-\mathrm{c}}$ Means within a column with different superscripts differ at the $P$-value shown

${ }^{1}$ Centipoise units

${ }^{2} \mathrm{SEM}=$ pooled standard error of mean.

${ }^{3}$ Significance level: $\dagger P \leq 0.1, * * * P \leq 0.0001$, NS (Not significant) $P>0.1$

\section{References}

Angel R, Saylor WW, Mitchell AD, Powers W and Applegate TJ. Effect of dietary phosphorus, phytase, and 25-hydroxycholecalciferol on broiler chicken bone mineralization, litter phosphorus, and processing yields. Poultry Science, 85: 12001211. 2006

Annison G and Choct M. Anti-nutritive activities of cereal nonstarch polysaccharides in broiler diets and strategies minimizing their effects. World's Poultry Science Journal, 47: 232242. 1991.

AOAC. Official methods of analysis, 16th ed. Association of Official Analytical Chemists. Washington, DC, U.S.A. 1998.

AOAC. Official methods of analysis, 15th ed. Association of Official Analytical Chemists. Washington, DC, U.S.A. 1990.

AOAC. Official methods of analysis, 18th ed. Association of Official Analytical Chemists. Washington, DC, U.S.A. 2006.

Applegate TJ, Joern BC, Nussbaum-Wagler DL and Angel R. Water-soluble phosphorus in fresh broiler litter is dependent upon phosphorus concentration fed but not on fungal phytase supplementation. Poultry Science, 82: 1024-1029. 2003.

Bar SHA. Calcium and Phosphorus Interrelationships in the
Intestine of the Fowl. Journal of Nutrition, 101: 677-686. 1971.

Bedford MR. Exogenous enzymes in monogastric nutrition-their current value and future benefits. Animal Feed Science and Technology, 86: 1-13. 2000.

Cadogan DJ, Selle PH, Creswell D and Partridge G. Phytate limits broiler performance and nutrient digestibility in sorghum based diets. Proceedings of the 17th Australian Poultry Science Symposium, Sydney, New South Wales, Australia, pp. 17: 39-43. 2005.

CCAC. Guide to the care and use of experimental animals, Volume 1. Canadian Council on Animal Care. Ottawa, ON. 1993.

Choct M. Feed non-starch polysaccharides: chemical structure and nutritional significance. Feed Milling International, June Issue pp. 13-26. 1997.

Cowieson AJ and Adeola O. Carbohydrases, protease, and phytase have an additive beneficial effect in nutritionally marginal diets for broiler chicks. Poultry Science, 84: 1860-1867. 2005.

Denstadli V, Ballance S, Knutsen SH, Westereng B and Svihus B. Influence of graded levels of brewers dried grains on pellet quality and performance in broiler chickens. Poultry Science, 89: 2640-2645. 2010. 
Dilger RN, Onyango EM, Sands JS and Adeola O. Evaluation of microbial phytase in broiler diets. Poultry Science, 83: 962970. 2004.

Englyst HN and Cummings JH. Improved method for measurement of dietary fiber as non-starch polysaccharides in plant foods. Journal of AOAC International, 71: 808-814. 1988.

García M, Lázaro R, Latorre MA, Gracia MI and Mateos GG. Influence of enzyme supplementation and heat processing of barley on digestive traits and productive performance of broilers. Poultry Science, 87: 940-948. 2008.

Graham KK, Kerley MS, Firman JD and Allee GL. The effect of enzyme treatment of soybean meal on oligosaccharide disappearance and chick growth performance. Poultry Science, 81: 1014-1019. 2002.

Han YW. Removal of phytic acid from soybean and cottonseed meals. Journal of Agricultural and Food Chemistry, 36: 11811183. 1988.

Jankowski J, Lecewicz A, Zdunczyk Z, Juskiewicz J and Slominski BA. The effect of partial replacement of soyabean meal with sunflower meal on ileal adaptation, nutrient utilisation and growth performance of young turkeys. British Poultry Science, 52: 456-465. 2011.

Jorgensen H, Zhao XQ, Knudsen KE and Eggum BO. The influence of dietary fibre source and level on the development of the gastrointestinal tract, digestibility and energy metabolism in broiler chickens. British Journal of Nutrition, 75: 379-395. 1996.

Knudsen KEB. Carbohydrate and lignin contents of plant materials used in animal feeding. Animal Feed Science and Technology, 67: 319-338. 1997.

Leytem AB, Plumstead PW, Maguire RO, Kwanyuen P and Brake J. What aspect of dietary modification in broilers controls litter water-soluble phosphorus. Journal of Environmental Quality, 36: 453-463. 2007.

Liu Z, Li T, Yin F, Wang S, Wang J, Zhan Z, Zhou Y and Huang R. Selecting the optimal levels of non-starch polysaccharides (NSP) degrading enzymes for NSP degradation in selected feed ingredient. International Journal of Food, Agriculture and Environment, 11: 428-435. 2013.

Lomer MC, Thompson RP, Commisso J, Keen CL and Powell JJ. Determination of titanium dioxide in foods using inductively coupled plasma optical emission spectrometry. Analyst, 125: 2339-2343. 2000.

Meng X and Slominski BA. Nutritive values of corn, soybean meal, canola meal, and peas for broiler chickens as affected by a multicarbohydrase preparation of cell wall degrading enzymes. Poultry Science, 84: 1242-1251. 2005.

Meng X, Slominski BA, Nyachoti CM, Campbell LD and Guenter W. Degradation of cell wall polysaccharides by combinations of carbohydrase enzymes and their effect on nutrient utilization and broiler chicken performance. Poultry Science, 84: 37-47. 2005.

NRC. Nutrient Requirements of Poultry, 9th rev. National Academy Press. Washington, DC. 1994.

Ojewola GS, Okoye FC and Agbakuru I. Replacement value of cashew-nut meal for soybean meal in finishing broiler chickens. International Journal of Poultry Science, 3: 513-516. 2004.

Onyango EM, Bedford MR and Adeola O. Efficacy of an evolved Escherichia coli phytase in diets of broiler chicks. Poultry Science, 84: 248-255. 2005.
Penn CJ, Mullins GL, Zelazny LW, Warren JG and McGrath JM. Surface runoff losses of phosphorus from Virginia soils amended with turkey manure using phytase and high available phosphorus corn diets. Journal of Environmental Quality, 33: 1431-1439. 2004.

Ravindran V, Bryden WL and Kornegay ET. Phytates: occurrence, bioavailability and implications to poultry nutrition. Poultry and Avian Biology Reviews, 6: 125-143. 1995.

Ravindran V, Selle PH and Bryden WL. Effects of phytase supplementation, individually and in combination, with glycanase, on the nutritive value of wheat and barley. Poultry Science, 78: 1588-1595. 1999.

Ravindran V, Morel PC, Partridge GG, Hruby M and Sands JS. Influence of an Escherichia coli-derived phytase on nutrient utilization in broiler starters fed diets containing varying concentrations of phytic acid. Poultry Science, 85: 82-89. 2006.

Rutherfurd SM, Chung TK and Moughan PJ. The effect of a commercial enzyme preparation on apparent metabolizable energy, the true ileal amino acid digestibility, and endogenous ileal lysine losses in broiler chickens. Poultry Science, 86: 665-672. 2007.

Scott RW. Colorimetric determination of hexuronic acids in plant materials. Analytical Chemistry, 51: 936-941. 1979.

Selle P, Ravindran V, Pittolo P and Bryden W. An evaluation of microbial phytase in sorghum-based broiler diets. Proceedings of Australian Poultry Science Symposium, 97-100. 1999.

Selle PH, Ravindran V and Partridge GG. Beneficial effects of xylanase and/or phytase inclusions on ileal amino acid digestibility, energy utilisation, mineral retention and growth performance in wheat-based broiler diets. Animal Feed Science and Technology, 153: 303-313. 2009.

Selle PH, Cadogan DJ, Ru YJ and Partridge GG. Impact of exogenous enzymes in sorghum- or wheat-based broiler diets on nutrient utilization and growth performance. International Journal of Poultry Science, 9: 53-58. 2010.

Shim MY, Pesti GM, Bakalli RI, Tillman PB and Payne RL. Evaluation of corn distillers dried grains with solubles as an alternative ingredient for broilers. Poultry Science, 90: 369376. 2011.

Singh $\mathrm{M}$ and Krikorian AD. Inhibition of trypsin activity in vitro by phytate. Journal of Agricultural and Food Chemistry, 30: 799800. 1982.

Slominski BA and Campbell LD. Non-starch polysaccharides of canola meal: Quantification, digestibility in poultry and potential benefit of dietary enzyme supplementation. Journal of the Science of Food and Agriculture, 53: 175-184. 1990.

Van Soest PJ, Robertson JB and Lewis BA. Methods for dietary fiber, neutral detergent fiber, and nonstarch polysaccharides in relation to animal nutrition. Journal of Dairy Science, 74: 3583-3597. 1991.

Wang JP, Hong SM, Yan L, Yoo JS, Lee JH, Jang HD, Kim HJ and Kim IH. Effects of single or carbohydrases cocktail in lownutrient-density diets on growth performance, nutrient digestibility, blood characteristics, and carcass traits in growing-finishing pigs. Livestock Science, 126: 215-220. 2009.

Zhang X, Roland DA, McDaniel GR and Rao SK. Effect of Natuphos phytase supplementation to feed on performance and ileal digestibility of protein and amino acids of broilers. Poultry Science, 78: 1567-1572. 1999. 